Situs Jurnal : $\underline{\text { http://ejurnal.stiepancasetia.ac.id/index.php/jieb }}$

Jilid 4 Nomor 1 Maret 2018

Hal $127-133$

\title{
PENGARUH GAYA KEPEMIMPINAN TERHADAP PRODUKTIVITAS KERJA PEGAWAI DINAS KETENAGAKERJAAN DAN TRANSMIGRASI KABUPATEN MURUNG RAYA PROVINSI KALIMANTAN TENGAH
}

\section{Firdaus dan Periyadi*}

Abstract: This study aims to determine whether there is influence of leadership style on work productivity employee employment and transmigration officers Murung Raya District either partially or simultaneously. The method used in this study is quantitative research is a research model that requires the existence of the calculation of the numbers, while the approach used is a survey approach that is the research that takes samples from the population and use the questionnaire as the main data collection tool. The results of this study indicate that leadership style influential and significant changes in the direction of work productivity Employee employment and transmigration officers Murung Raya District. This means that if the level of influence of leadership style perceived higher, then lead to higher productivity also work.

Keywords: leadership style, productivity

Abstrak: Penelitian ini bertujuan untuk mengetahui ada tidaknya pengaruh gaya kepemimpinan terhadap produktivitas kerja pegawai dinas ketenagakerjaan dan transmigrasi Kabupaten Murung Raya baik secara parsial maupun simultan. Metode yang digunakan dalam penelitian ini adalah penelitian kuantitatif yaitu suatu model penelitian yang mengharuskan akan adanya perhitungan angka-angka, sedangkan pendekatan yang digunakan adalah dengan pendekatan survei yaitu penelitian yang mengambil sampel dari populasi dan menggunakan kuesioner sebagai alat pengumpulan data yang pokok. Hasil penelitian ini menunjukan bahwa gaya kepemimpinan berpengaruh secara siginifikan dan perubahannya berubah searah dengan Produktivitas kerja pegawai dinas ketenagakerjaan dan transmigrasi Kabupaten Murung Raya. Artinya jika tingkat pengaruh gaya kepemimpinan yang dirasakan makin tinggi , maka mengakibatkan makin tinggi juga Produktivitas kerja.

Kata kunci : gaya kepemimpinan, produktivitas

\section{Latar Belakang}

Organisasi merupakan suatu wadah bagi orang-orang untuk berkumpul dan bekerja sama untuk mencapai tujuan bersama. Dalam organisasi tentunya perlu adanya hirarki pimpinan dan bawahan. Oleh karena itu perlu adanya sumberdaya manusia yang berkualitas untuk menjadi pimpinan dan bawahan. Sudarsono $(2006,67)$ mengungkapkan bahwa sumberdaya manusia adalah tenaga yang berpotensi dan tidak dapat dipisahkan dari organisasi atau unit kerja. Peran seorang pemimpin dalam mempengaruhi bawahannya sangatlah penting bagi kemajuan organisasi tersebut. Koesmono (2007, 30) mengungkapkan bahwa keberadaan seorang pemimpin dalam organisasi dibutuhkan untuk membawa organisasi kepada tujuan yang telah ditetapkan. Pemimpin biasanya menerapkan gaya kepemimpinan tertentu untuk mempengaruhi kinerja bawahannya. 
Menurut Robert House sebagaimana dikutip oleh Robbins (2007, 448) mengungkapkan bahwa terdapat empat macam klasifikasi kepemimpinan yakni gaya kepemimpinan direktif, gaya kepemimpinan suportif, gaya kepemimpinan partisipatif, dan gaya kepemimpinan berorientasi pada tugas. Bermacam-macam gaya kepemimpinan dapat digunakan oleh seorang pemimpin untuk mempengaruhi dan memotivasi bawahannya, sehingga dapat meningkatkan kinerja bawahannya dalam melakukan pekerjaan.

Tercapainya tujuan organisasi hanya dimungkinkan karena upaya para pelaku yang terdapat dalam organisasi untuk berkinerja dengan baik. Seorang bawahan yang memiliki kinerja yang tinggi dan baik dapat menunjang tercapainya tujuan dan sasaran yang telah ditetapkan oleh sebuah organisasi. Untuk dapat memiliki kinerja yang tinggi dan baik, seorang karyawan atau bawahan dalam melaksanakan pekerjaannya harus memiliki keahlian dan keterampilan yang sesuai dengan pekerjaan yang ditekuninya. Namun, kadang kala pimpinan kerap kali memerintahkan para bawahannya dengan sesuka hati tanpa memperhatikan kondisi bawahannya. Sehingga hal tersebut akan berdampak pada kinerja bahawahannya yang kurang baik. Ketidak mampuan bawahan menjalankan tugasnya sesuai dengan tanggung jawab mereka bukan disebabkan karena bawahan tidak mampu mengerjakan tugas tersebut dengan baik. Namun hal ini dapat terjadi karena bawahan tersebut tidak dapat menyesuaikan gaya kepemimpinan para pemimpinnya sendiri sehingga para bawahan tersebut merasa kurang dihargai oleh pemimpin yang yang ada dalam organisasi. Apabila kinerja kurang baik maka hal tersebut akan berdampak pada tugas-tugas yang harus dikerjakan oleh para bawahannya. Oleh karena itu, seorang pemimpin harus mengubah gaya kepemimpinan yang dapat memberikan kenyamanan bagi bagi para bawahannya yang bekerja dalam suatu organisasi.

\section{Kajian Literatur}

Menurut Robbert D Stuart (2002) bahwa pemimpin adalah seorang yang diharapkan mempunyai kemampuan untuk mempengaruhi, memberi petunjuk dan juga mampu menentukan individu untuk mencapai tujuan organisasi. Seiring dengan itu James P. Spillane (2006) menyatakan bahwa pemimpin itu agen perubahan dengan kegiatan mempengaruhi orang-orang dari pada pengaruh orang-orang tersebut kepadanya. Kreitner dan Kinicki (2005, .299) mengungkapkan bahwa kepemimpinan atau leadership didefinisikan sebagai suatu proses pengaruh sosial dimana pemimpin mengusahakan partisipasi sukarela dari para bawahan dalam suatu usaha untuk mencapai tujuan organisasi. Maka kepemimpinan adalah suatu proses dimana seseorang mempengaruhi orang lain untuk menjadi bawahan dalam mencapai tujuan bersama.

Richard L. Daff (2010) mengemukakan Kepemimpinan (leadership) adalah merupakan suatu pengaruh hubungan antara pimpinan dan pengikut (followers) yang bermaksud pada perubahan dan hasil nyata yang mencerminkan tujuan bersama. Dari beberapa pendapat diatas dapat disimpulkan bahwa kepemimpinan merupakan sebuah hubungan yang saling mempengaruhi diantara pemimpin dan pengikut (bawahan) yang menginginkan perubahan nyata yang mencerminkan tujuan bersama. Untuk dapat mencapai produktivitas kerja dalam penelitian ini sebagai kerangka pikir mengacu pada pendapat Robert House sebagaimana dikutip oleh Wirjana dan Supardo (2005, .49), mengungkapkan bahwa seseorang pemimpin menggunakan suatu gaya kepemimpinan yang tergantung dari situasi, yakni:

1. Kepemimpinan Direktif

Pemimpin memberikan nasihat spesifik kepada kelompok dan memantapkan peraturan-peraturan pokok.

2. Kepemimpinan Suportif

Adanya hubungan yang baik antara pemimpin dengan kelompok dan memperlihatkan kepekaan terhadap kebutuhan anggota. 
3. Kepemimpinan Partisipatif

Pemimpin mengambil keputusan berdasarkan konsultasi dengan kelompok, dan berbagi informasi dengan kelompok.

4. Kepemimpinan Orientasi Prestasi

Pemimpin menghadapkan anggota-anggota pada tujuan yang menantang, dan mendorong kinerja yang tinggi, sambil menunjukkan kepercayaan pada kemampuan kelompok.

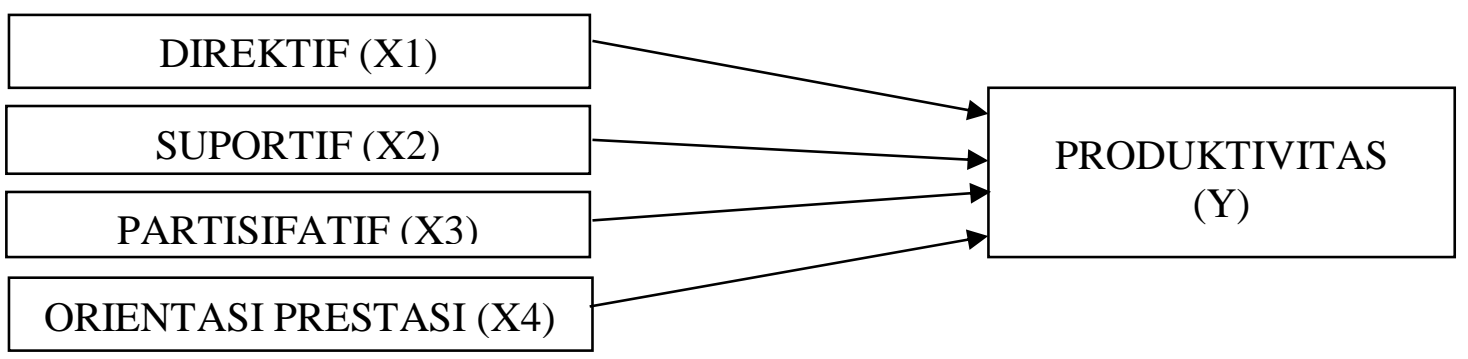

\section{Gambar 1. Kerangka Konseptual dan Hipotesis}

Berdasarkan model konseptual pada Gambar 1, maka hipotesis dalam penelitian ini adalah sebagai berikut:

H1: Gaya kepemimpinan yang teridiri atas kepemimpinan direktif, suportif, partisipatif dan orientasi prestasi berpengaruh signifikan secara simultan terhadap produktivitas.

$\mathrm{H} 2$ : Gaya kepemimpinan yang teridiri atas kepemimpinan direktif, suportif, partisipatif dan orientasi prestasi berpengaruh signifikan secara parsial terhadap produktivitas.

\section{Metode Penelitian}

Objek penelitian adalah seluruh pegawai kantor Dinas Ketenagakerjaan dan Transmigrasi Kabupaten Murung Raya. Teknik pengambilan sampel yang digunakan dalam penelitian ini adalah stratified random sampling. Umar (2003) mengatakan bahwa stratified random sampling merupakan metode pengambilan sampel dengan cara mengelompokkan suatu populasi yang dianggap heterogen menurut suatu karakteristik tertentu ke dalam beberapa subpopulasi sehingga tiap kelompok akan memiliki anggota sampel yang relatif homogen.

Dalam rangka memperoleh data untuk penelitian ini digunakan teknik pengumpulan data yang digunakan adalah observasi, dokumentasi, dan kuisioner. Data yang telah terkumpul setelah dilakukan uji validitas dan reabilitasnya, akan dianalisis secara kuantitatif deskriftif dan imferensial. Teknik uji validitas dengan menggunakan product moment pearson. Sedangkan untuk uji reabilitas instrumen yaitu dengan melihat nilai Alpha Cronbuch.

Sebelum dilakukan pengujian dengan analisis regresi, data penelitian diuji dengan uji asumsi klasik yang terdiri dari : uji normalitas, uji heterokedastisitas, dan uji multikolonieritas. Kemudian untuk pengujian hipotesis secara simultan menggunakan Uji F, dan untuk pengujian hipotesis secara parsial menggunakan Uji t. Sedangkan untuk menentukan variabel yang paling dominan mempengaruhi produktivitas menggunakan nilai standrdized coefficient beta.

\section{Hasil Penelitian dan Pembahasan}

Langkah pertama dalam analisis ini adalah melakukan uji validitas dan reliabilitas. Penelitian ini dinyatakan valid dan reliabel seperti ditunjukkan pada Tabel 1 dan 2.

\section{Tabel 1 Hasil Ringkasan Hasil Uji Validitas}

\begin{tabular}{lllll} 
Variabel & $\begin{array}{c}\text { Butir } \\
\text { pertanyaan }\end{array}$ & $\mathrm{r}$ & $\mathrm{p}$ & Status \\
\hline
\end{tabular}




\begin{tabular}{ccccc}
\hline X1 & X1.1 & 0,856 & 0,000 & Valid \\
\cline { 2 - 4 } Direktif & X1.2 & 0,801 & 0,000 & Valid \\
\cline { 2 - 4 } & X1.3 & 0,862 & 0,000 & Valid \\
\hline X2 & X2.1 & 0,853 & 0,000 & Valid \\
\cline { 2 - 4 } Suportif & X2.2 & 0,836 & 0,000 & Valid \\
\hline X2.3 & 0,878 & 0,000 & Valid \\
\hline X3 & X3.1 & 0,841 & 0,000 & Valid \\
\cline { 2 - 4 } Partisifatif & X3.2 & 0,789 & 0,000 & Valid \\
\hline X3.3 & 0,812 & 0,000 & Valid \\
\hline X4 & X4.1 & 0,838 & 0,000 & Valid \\
\cline { 2 - 4 } Orientasi & X4.2 & 0,824 & 0,000 & Valid \\
\hline Prestasi & X4.3 & 0,881 & 0,000 & Valid \\
\hline Y & Y1.1 & 0,822 & 0,000 & Valid \\
\cline { 2 - 4 } Produktivitas & Y1.2 & 0,862 & 0,000 & Valid \\
\cline { 2 - 4 } & Y1.3 & 0,839 & 0,000 & Valid \\
\hline
\end{tabular}

Tabel 2 Hasil Ringkasan Uji Reabilitas Kuisioner

\begin{tabular}{|c|c|c|c|}
\hline Variabel & Nilai Alpha Cronbach & Nilai Kritis & Status \\
\hline X1 : Direktif & 0.894 & 0,60 & Reliabel \\
\hline X2 : Suportif & 0.907 & 0,60 & Reliabel \\
\hline X3 : Partisifatif & 0.864 & 0,60 & Reliabel \\
\hline $\mathrm{X} 4$ : Orientasi Prestasi & 0.900 & 0,60 & Reliabel \\
\hline Y : Produktivitas & 0.893 & 0,60 & Reliabel \\
\hline
\end{tabular}

Langkah selanjutnya adalah melakukan uji asumsi klasik, dengan urutan pengujian sebagai berikut:

1. Uji Multikolinearitas

Hasil uji Multikolinearitas ditunjukkan pada Tabel 3. Karena nilai VIF dari masing-masing variabel bebas semuanya dibawah 5 , maka penelitian ini bebas masalah multikolinearitas.

Tabel 3. Hasil Uji Multikolinieritas

\begin{tabular}{llll}
\hline Variabel & Tolerance & VIF & Kesimpulan \\
\hline Direktif (X1) & .420 & 2.384 & Tidak terjadi multikolinieritas \\
\hline Suportif $(\mathrm{X} 2)$ & .290 & 2.448 & Tidak terjadi multikolinieritas \\
\hline Partisifatif $(\mathrm{X} 3)$ & .437 & 2.290 & Tidak terjadi multikolinieritas \\
\hline Orientasi Prestasi (X4) & .449 & 2.225 & Tidak terjadi multikolinieritas \\
\hline
\end{tabular}

\section{Uji Autokorelasi}

Untuk dapat mendiagnosis adanya autokorelasi dalam suatu model regresi dilakukan melalui pengujian terhadap nilai uji Durbin-Watson (Uji DW) dengan ketentuan sebagai berikut:
- DW Kurang dari 1,10
: Ada Autokorelasi
- DW diantara 1,10 dan 1,54
: Tanpa Kesimpulan
- DW diantara 1,55 dan2,46
: Tidak Ada Autokrelasi
- DW diantara 2,46 dan 2,90
: Tanpa Kesimpulan
- DW Lebih dari 2,91
: Ada Autokorelasi

Berdasarkan pengujian yang dilakukan ditemukan bahwa nilai DW $=2,098$, maka dapat disimpulkan bahwa tidak terdapat autokorelasi.

\section{Uji Heteroskedastisitas}

Diagnosis adanya Heteroskedastisitas dapat dilakukan dengan metode Uji Gletsejer yaitu jika nilai signifikan $t>0.05$ maka tidak dapat terjadi Heteroskedastisitas. Pada hasil uji 
Heteroskedastisitas seperti pada tabel 4 ternyata untuk semua variabel independent hasil regresi atas variabelnya diperoleh hasil yang lebih besar dari 0,05 sehingga keputusannya adalah bahwa dalam model tidak terjadi Heteroskedastisitas yang artinya analisis dapat dilanjutkan.

Tabel 4. Hasil Uji Heteroskedastisitas

\begin{tabular}{llll}
\hline Variabel & thitung $_{\text {Sig. }}$ & Seputusan \\
\hline Direktif $(\mathrm{X} 1)$ & 4,184 & 0,000 & Tidak terjadi Heteroskedastisitas \\
\hline Suportif $(\mathrm{X} 2)$ & 0,251 & 0,802 & Tidak terjadi Heteroskedastisitas \\
\hline Partisifatif (X3) & 2,150 & 0,034 & Tidak terjadi Heteroskedastisitas \\
\hline Orientasi Prestasi (X4) & 12,780 & 0,000 & Tidak terjadi Heteroskedastisitas \\
\hline
\end{tabular}

Langkah selanjutnya adalah pengujian analisis regresi berganda untuk melihat pengaruh dari semua variabel bebas terhadap produktivitas, yang ditunjukkan pada Tabel 5.

Tabel 5. Hasil Koefisien Regresi Linier Berganda PT. Grafika Wangi Kalimantan.

\begin{tabular}{lll}
\hline Variabel & b & Koefisien \\
\hline Direktif $(\mathrm{X} 1)$ & $\mathrm{b} 1$ & .179 \\
\hline Suportif $(\mathrm{X} 2)$ & $\mathrm{b} 2$ & .087 \\
\hline Partisifatif $(\mathrm{X} 3)$ & $\mathrm{b} 3$ & .105 \\
\hline Orientasi Prestasi $(\mathrm{X} 4)$ & $\mathrm{b} 4$ & .707 \\
\hline
\end{tabular}

Dari tabel 5 dapat dibuat persamaan Regresi yang terbentuk adalah sebagai berikut:

$\mathrm{Y}=0,298+0,179 \mathrm{X} 1+0,087 \mathrm{X} 2+0,105 \mathrm{X3}+0,707 \mathrm{X} 4+\mathrm{e}$

Uji F dilakukan untuk melihat kemampuan dari semua variabel bebas untuk secara simultan mempengaruhi produktivitas. Teknik uji $\mathrm{F}$ yang dipergunakan yaitu dengan membandingkan antara $\mathrm{F}$ hitung dengan $\mathrm{F}$ tabel, jika $\mathrm{F}$ hitung lebih besar dari $\mathrm{F}$ tabel maka keputusannya adalah $\mathrm{H}_{\mathrm{o}}$ dan $\mathrm{H}_{\mathrm{a}}$ diterima. Dengan tingkat keyakinan $95 \%$ dan derajat kebebasan $(\mathrm{k}-1)(\mathrm{n}-\mathrm{k})$ maka tabel untuk F $(0,05)(4)(97)=2,3092$. Dalam penelitian ini ditemukan bahwa F hitung sebesar 24.298, jauh diatas 2,3092 yang artinya variabel X1, X2, X3 dan X4 secara bersama-sama berpengaruh pada Produktivitas Kerja Pegawai Dinas Ketenagakerjaan dan Transmigrasi Kabupaten Murung Raya.

Untuk menguji pengaruhnya secara parsial digunakanlah uji t. Teknik uji t yang dilakukan yaitu dengan melihat nilai t signifikan pada hasil pengolahan data melalui SPSS. Dalam penelitian ini $\alpha$ yang digunakan yaitu sebesar $5 \%(0,05)$. Keputusannya, jika nilai t signifikan $<$ terhadap $\alpha$ maka $\mathrm{H}_{0}$ akan ditolak dan menerima $\mathrm{H}_{\mathrm{a}}$.

Tabel 6. Hasil Rangkuman Nilai T Signifikan

\begin{tabular}{lll}
\hline \multicolumn{1}{c}{ Variabel } & Signifikan $\mathrm{t}$ & \multicolumn{1}{c}{$\mathrm{H}_{\mathrm{a}}$ diterima/ditiolak } \\
\hline Direktif $(\mathrm{X} 1)$ & .188 & Diterima \\
\hline Suportif $(\mathrm{X} 2)$ & .579 & Diterima \\
\hline Partisifatif $(\mathrm{X} 3)$ & .377 & Diterima \\
\hline Orientasi Prestasi (X4) & .000 & Diterima \\
\hline
\end{tabular}

Dari hasil rangkuman nilai $\mathrm{t}$ signifikan pada tabel 6 diatas terlihat bahwa, nilai signifikan t untuk X4 =0,000, artinya X4 (Orientasi Prestasi) signifikan dalam mempengaruhi 
Produktivitas Kerja. Jadi variabel X4 (Orientasi Prestasi) signifikan dalam mempengaruhi Y (Produktivitas Kerja) atau $\mathrm{H}_{0}$ ditolak dan $\mathrm{H}_{\mathrm{a}}$ diterima.

Untuk Variabel X1 (Direktif) nilai signifikan T lebih besar dari 5\% yaitu 0,188 . Untuk Variabel X2 (Suportif) nilai signifikan T lebih besar dari 5\% yaitu 0,579. Untuk Variabel X3 (Partisifatif) nilai signifikan T lebih besar dari 5\% yaitu 0.377 . Jadi variabel $\mathrm{X} 1, \mathrm{X} 2$ danX3 signifikan dalam mempengaruhi $\mathrm{Y}$ (Produktivitas Kerja) atau $\mathrm{H}_{0}$ ditolak dan $\mathrm{H}_{\mathrm{a}}$ diterima.

Sutrisno Hadi (1996) dalam penjelasannya mengenai kaidah uji hipotesis penelitian, jika hasil peluang ralat $(\mathrm{p})<0,15$ hasilnya dikategorikan cukup signifikan artinya $\mathrm{H}_{0}$ ditolak dan $\mathrm{H}_{\mathrm{a}}$ diterima.

Dari hasil analisis yang dilakukan, diperoleh bahwa variabel variabel Gaya Kepemimpinan yang terdiri dari Direktif, Suportif, Partisifatif dan Orientasi Prestasi berpengaruh secara siginifikan dan perubahannya berubah searah dengan tingkat Produktivitas kerja. Artinya jika tingkat pengaruh gaya kepemimpinan yang dirasakan oleh pegawai Dinas Ketenagakerjaan dan Transmigrasi Kabupaten Murung Raya makin tinggi, maka mengakibatkan makin tinggi juga tingkat Produktivitas Kerja Pegawainya. Oleh karena itu, Persamaan regresi yang didapat dari hasil analisis tersebut adalah:

\section{$\mathrm{Y}=0,298+0,179 \mathrm{X} 1+0,087 \mathrm{X} 2+0,105 \mathrm{X3}+0,707 \mathrm{X} 4+\mathrm{e}$}

Untuk melihat dominasi pengaruh dari variabel bebas terhadap variabel terikatnya, maka bisa dilihat koefisien beta (koefisien regresi baku). Nilai koefisien regresi baku antar variabel bebas dapat dibandingkan, karena nilainya telah distandarisasi sehingga variabel bebas (Gaya Kepemimpinan) yang memiliki koefisien regresi baku yang lebih besar, berarti akan memberi pengaruh yang lebih besar pula pada variabel terikatnya.

Variabel bebas yang memiliki beta terbesar adalah variabel Orientasi Prestasi (X4) yaitu sebesar 0,707 (Lihat table 6). Oleh karena itu dapat dikatakan bahwa variabel Orientasi Prestasi (X4) yang memiliki pengaruh terbesar terhadap Produktivitas Kerja adalah variabel X4 yaitu dengan koefisien regresi baku sebesar 0,707. Hasil pembuktian hipotesa pertama (H1) yaitu keputusannya menolak $\mathrm{H}_{0}$ dan menerima $\mathrm{H}_{\mathrm{a}}$ yang artinya uji $\mathrm{F}$ terhadap persamaan regresi yang diperoleh dari penelitian ini menunjukan hasil bahwa, secara bersama-sama ke-empat variabel Gaya Kepemimpinan berpengaruh terhadap tingkat Produktivitas Kerja Pegawai Dinas Ketenagakerjaan dan Transmigrasi Kabupaten Murung Raya.

Implikasi hasil uji F bagi pemimpin di kantor Dinas Ketenagakerjaan dan Transmigrasi Kabupaten Murung Raya adalah jika pemimpin ingin meningkatkan tingkat Produktivitas Kerja pegawainya maka perlu menekankan pada empat faktor tersebut yaitu berturut-turut Gaya Kepemimpinan yang bersifat Direktif, Suportif, Partisifatif dan Orientasi Prestasi Hal ini harus dilakukan secara terus menerus (continues improvement) dalam usaha untuk meningkatkan hasil kinerja bawahannya.

Untuk mendukung keterangan diatas dapat juga kita lihat hasil $\mathrm{R}^{2}$ (Koefisien Determinasi) Regresi yaitu sebesar 0,674 atau $67,4 \%$. Hal ini dapat diartikan bahwa sebanyak 67.4\% Tingkat Produktivitas Kerja dijelaskan oleh variabel Gaya Kepemimpinan. Sedangkan sisanya sebesar $32.6 \%$ dijelaskan oleh variabel lain diluar variabel Gaya Kepemimpinan yang terdiri dari Direktif, Suportif, Partisifatif dan Orientasi Prestasi.

\section{DAFTAR PUSTAKA}

Ghozali, Imam. 2005. Aplikasi Analisis Multivarite dengan SPSS. Cetakan Keempat. Semarang : Universitas Diponegoro.

Jonathan, Sarwono. 2006. Metode Penelitian kuantitatif dan kualitatif. Yogyakarta : Graha Ilmu. 
Marihot, Tua. 2000. Manajemen Sumber Daya Manusia, Edisi pertama. Yogyakarta.

Notoatmodjo, Soekidjo.2003. Pengembangan Sumber Daya Manusia. Edisi ketiga. Jakarta : PT. Rineka Cipta.

Simamora. 2006. Manajemen Sumber Daya Manusia. STIE YPKN. Yogyakarta.

Sulistyani, Ambar Teguh. (2008). Kepemimpinan Profesional : Pendekatan Leadrership Games. Yogyakarta : Gava Media.

Undang Undang No. 5 Tahun 2014 Tentang Aparatur Sipil Negara Pada Pasal 11 Mengenai Tugas Pegawai Aparatur Sipil Negara

Qomariah, Inneke. (2005). "Pengaruh Gaya Kepemimpinan Terhadap Kinerja Pegawai Pada Asisten Administrasi Kesekretariatan Daerah Provinsi Sumatera Utara" (Skripsi). Sumatera Utara: Universitas Sumatera Utara. 